\title{
Pertumbuhan dan Produksi Benih Iles-iles (Amorphophallus muelleri Blume) Asal Teknik Budi Daya yang Berbeda
}

\author{
Growth and Production Iles-iles (Amorphophallus muelleri Blume) from Different of Cultivation \\ Techniques
}

\section{Nurul Hidayah, M. Rahmad Suhartanto* dan Edi Santosa}

\author{
Departemen Agronomi dan Hortikultura, Fakultas Pertanian, Institut Pertanian Bogor (Bogor Agricultural \\ University), Jalan Meranti, Kampus IPB Dramaga, Bogor 16680, Indonesia \\ Telp.\& Faks.021-8629353 email: agronipb@indo.net.id \\ *Penulis untuk korespondensi : otnat@yahoo.com
}

Disetujui 20 Agustus 2018 / Published online 3 September 2018

\begin{abstract}
Amorphophallus muelleri is a native Indonesian plant that has been used for generations. The demand of Amorphophallus muelleri seed increase as the demand of bulbs. The availability of seeds to meet tuber production is still being pursued to make market demand sufficient. This study aims to know the growth and production of iles-iles seed from a different cultivation techniques. The seeds used are A. muelleri seeds from cultivation techniques using GA3, water saturated, and soil. The research used a Complete Randomized Group Design (RKLT) single factor with four replications. The results showed that growth of iles-iles include petiol length and canopy width are not significant from the three cultivation. Same with the production component include bulb diameters, bulb length, and wet bulb weight are not significant. Based on the result, can be concluded that seed from soil, $\mathrm{GA}_{3}$ induction, and water saturated cultivation techniques of iles-iles are not affect to growth and production.
\end{abstract}

Keywords : $G A_{3}$ induction, water saturated, seed production, cultivation technique

\begin{abstract}
ABSTRAK
Amorphophallus muelleri merupakan tanaman asli Indonesia yang telah dimanfaatkan secara turun temurun. Permintaan benih A. muelleri terus meningkat seiring dengan meningkatnya permintaan umbi. Ketersediaan benih untuk memenuhi produksi umbi masih terus diupayakan agar permintaan pasar tercukupi. Penelitian ini bertujuan untuk mengetahui pertumbuhan dan produksi benih iles-iles yang berasal dari teknik budi daya yang berbeda. Benih yang digunakan yaitu benih dari hasil teknik budi daya menggunakan $\mathrm{GA}_{3}$, jenuh air, dan tanah. Rancangan yang digunakan yaitu Rancangan Kelompok Lengkap Teracak (RKLT) faktor tunggal dengan empat ulangan. Hasil penelitian menunjukkan bahwa pertumbuhan iles-iles meliputi panjang petiol dan lebar tajuk dari benih asal ketiga teknik budi daya tidak berbeda nyata. Demikian pula komponen hasil budi daya yang meliputi diameter umbi, tinggi umbi, dan bobot basah umbi tidak berbeda nyata. Berdasarkan hasil yang diperoleh dapat disimpulkan bahwa benih hasil teknik budi daya tanah, induksi $\mathrm{GA}_{3}$, dan jenuh air pada iles-iles tidak mempengaruhi pertumbuhan dan produksi.
\end{abstract}

Kata kunci : induksi $\mathrm{GA}_{3}$, jenuh air, produksi benih, teknik budi daya 


\section{PENDAHULUAN}

Amorphophallus termasuk dalam famili Araceae, dengan anggota genus lebih dari 180 spesies dan penyebarannya didominasi oleh Asia dan Afrika. Salah satu spesies yang termasuk dalam genus Amorphophallus yaitu Amorphophallus muelleri Blume. Iles-iles merupakan tanaman asli Indonesia, yang telah dimanfaatkan secara turun temurun. Iles-iles memiliki kandungan glukomannan yang tinggi dan telah dimanfaatkan sebagai sumber karbohidrat dan bahan baku industri khususnya industri pangan. Di Indonesia, Amorphophallus muelleri sering disebut dengan iles-iles, porang atau coplok (Jawa Timur) dan lotrok (Yogyakarta) (Sugiyama and Santosa, 2008). Iles-iles banyak dibudidayakan di hutan-hutan secara tumpangsari.

Teknologi budi daya iles-iles mulai dari pembibitan hingga panen telah terpetakan dengan baik dan tersusun dalam SOP budi daya iles-iles (Santosa, 2014). Namun, ketersediaan benih unggul masih menjadi tantangan untuk pengembangan iles-iles. Perbanyakan iles-iles pada awalnya menggunakan umbi dan "bulbil". Hal tersebut karena perbanyakan menggunakan biji membutuhkan waktu produksi biji yang cukup lama.

Sejalan dengan semakin populernya penggunaan biji untuk perbanyakan tanaman ilesiles, kebutuhan benih terus meningkat. Cara produksi benih iles-iles masih belum banyak dikaji. Menurut Santosa et al. (2016), benih ilesiles berkembang dengan mengandalkan cadangan makanan dari umbi. Banyak tanaman iles-iles yang berkembang tanpa menghasilkan akar selama pembesaran dan pematangan biji. Hal tersebut mengindikasikan bahwa cara produksi benih iles-iles perlu dikaji lebih mendalam.

Pada penelitian ini, benih iles-iles yang diperoleh dari berbagai cara budi daya dibandingkan untuk mengetahui cara terbaik untuk menghasilkan benih. Salah satu yang dibandingkan adalah benih iles-iles hasil pertanaman dengan induksi $\mathrm{GA}_{3}$. Penggunaan $\mathrm{GA}_{3}$ merupakan salah satu cara untuk mempercepat pembungaan dan produksi biji. Menurut Santosa et al. (2006) $\mathrm{GA}_{3}$ dapat menginduksi pembungaan pada Amorphophallus paeoniifolius (Dennst.) Nicolson sekalipun pada umbi umur satu tahun, walaupun kadang-kadang menyebabkan morfologi bunga yang dihasilkan abnormal. Pertumbuhan vegetatif dari biji hasil induksi $\mathrm{GA}_{3}$ perlu diteliti lebih lanjut, termasuk adanya efek residu.

Pembanding lainnya adalah benih hasil budi daya jenuh air dan tanah. Seiring dengan peningkatan permintaan iles-iles dan kurangnya lahan produksi menyebabkan lahan pasang surut menjadi salah satu potensi untuk meningkatkan produktivitas iles-iles. Maka dari itu, pembandingan hasil produksi dari asal benih yang berbeda menjadi fokus dalam penelitian ini. Benih yang digunakan pada penelitian ini yaitu benih iles-iles dari hasil teknik budi daya menggunakan $\mathrm{GA}_{3}$, jenuh air, dan tanah. Penelitian ini bertujuan untuk mengetahui pertumbuhan dan produksi dari benih yang berasal dari teknik budi daya yang berbeda.

\section{BAHAN DAN METODE}

Penelitian dilaksanakan di Kebun Percobaan Leuwikopo IPB, Darmaga, Bogor. Kegiatan penelitian dilaksanakan selama delapan bulan dimulai pada bulan Oktober 2016 sampai dengan Mei 2017. Bahan yang digunakan yaitu benih iles-iles asal induksi $\mathrm{GA}_{3}$, benih asal teknik budi daya tanpa tanah, benih asal teknik budi daya tanah, pupuk kandang, pupuk N, P, dan K. Alat yang digunakan adalah timbangan digital, jangka sorong, paranet $55 \%$, dan sprinkler.

Penelitian menggunakan Rancangan Kelompok Lengkap Teracak (RKLT) faktor tunggal dengan uji lanjut Duncan Multiple Range Test (DMRT). Asal benih terdiri dari hasil induksi $\mathrm{GA}_{3}$, budi daya tanpa tanah (media air), dan budi daya tanah. $\mathrm{GA}_{3}$ yang digunakan untuk induksi bunga adalah 1000 ppm. Masing-masing asal benih iles-iles ditanam dalam empat ulangan. Prosedur penelitian meliputi persiapan benih, pengolahan lahan, penanaman benih, dan pemeliharaan tanaman.

Persiapan benih yang dilakukan yaitu menyiapkan 720 benih iles-iles yang terdiri dari 240 benih hasil induksi $\mathrm{GA}_{3}, 240$ benih hasil teknik budi daya jenuh air, dan 240 benih hasil teknik budi daya tanah biasa. Setelah itu, membersihkan benih dari kulit ari, lalu dicuci dan kemudian dikeringanginkan. Pengolahan lahan menggunakan traktor kemudian cangkul. Setelah itu, memasang paranet dengan naungan 55\%. Pada saat pengolahan tanah, dilakukan penaburan kapur sebanyak 1 ton $\mathrm{ha}^{-1}$. Bedengan ukuran $5 \times 1$ $\mathrm{m}$ diberi pupuk kandang dengan dosis 10 ton $\mathrm{ha}^{-1}$ digunakan untuk menanam biji.

Penanaman benih iles-iles dilakukan dengan jarak $25 \mathrm{~cm} \times 25 \mathrm{~cm}$ dengan satu butir benih per lubang tanam. Dengan demikian, setiap bedengan terdiri atas 60 tanaman. Pemeliharaan tanaman iles-iles meliputi penyiraman, penyiangan, pemupukan, dan penyemprotan hama penyakit. Penyiraman dilakukan menggunakan 
sprinkler yang dilakukan setiap dua hari sekali. Pengendalian gulma dilakukan secara manual agar tidak mengganggu pertumbuhan tanaman yang dilakukan setiap saat. Pemupukan dilakukan menggunakan $\mathrm{N}$, $\mathrm{P}$, dan $\mathrm{K}$ yang dilakukan saat 0 MST, dengan dosis berturut-turut adalah 100, 60, dan $80 \mathrm{~kg} \mathrm{~N}, \mathrm{P}, \mathrm{K}$ per hektar.

Pengamatan pertumbuhan tanaman dilakukan mulai 1 Minggu Setelah Tanam (MST) sampai dengan 25 MST. Data yang dikumpulkan meliputi persentase daya tumbuh, panjang petiol, lebar kanopi, morfologi daun, diameter umbi, dan bobot umbi. Pengukuran panjang petiol, lebar kanopi, dan morfologi daun dilakukan pada daun pertama, kedua, dan ketiga. Waktu pengukuran setiap daun berbeda-beda menyesuaikan dengan waktu munculnya daun. Pengukuran diameter umbi dan bobot umbi dilakukan setelah 34 MST yaitu saat tanaman telah mengalami dormansi. Selain itu, tanaman iles-iles asal umbi umur tiga tahun yang sedang berbunga diamati hingga menghasilkan biji untuk mengetahui perkembangannya. Data yang diperoleh dianalisis untuk mengetahui pengaruh dari perlakuan dengan melakukan uji $\mathrm{F}$ pada taraf nyata $\alpha=5 \%$. Jika terdapat beda nyata antar perlakuan, maka dilakukan uji lanjut menggunakan Duncan Multiple Range Test (DMRT) pada software SAS.

\section{HASIL DAN PEMBAHASAN}

\section{Perkembangan Biji Iles-iles}

Perkembangan biji iles-iles mulai dari berbunga sampai pemasakan biji memerlukan waktu yang cukup lama. Iles-iles mulai berbunga setelah umbi berumur tiga tahun. Pemasakan biji iles-iles mulai dari berbunga memerlukan waktu sekitar 12 bulan (Santosa et al., 2016). Dibandingkan dengan tanaman Araceae yang lain, yakni Colocasia esculenta (L.) Schott, iles-iles berbunga jauh lebih lambat. Menurut Prana (2007) Colocasia esculenta (L.) Schott berbunga setelah berumur 6-8 bulan. Berdasarkan pengamatan yang dilakukan, biji iles-iles dapat dipanen 9-10 bulan setelah anthesis (Gambar 1).

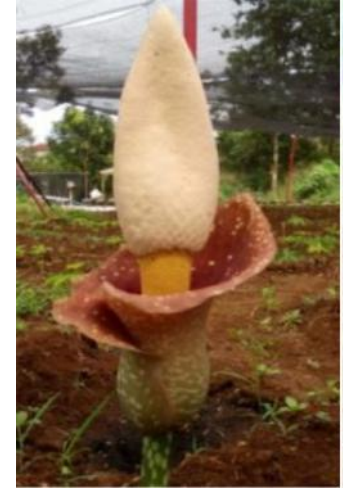

a)

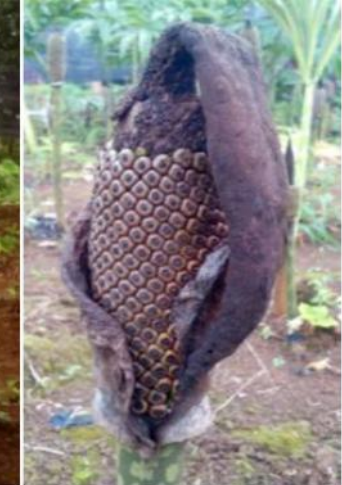

b)

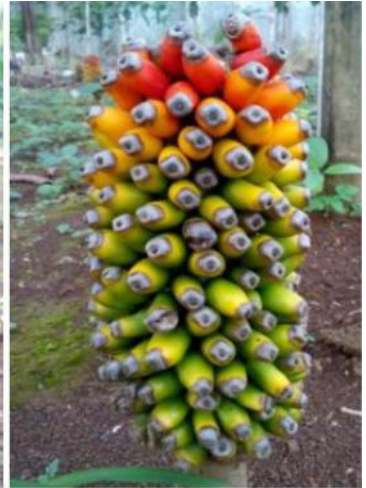

c)

Gambar 1. Perkembangan biji iles-iles. (a) Bunga mekar sempurna 1 MSA (minggu setelah anthesis), (b) Biji muda umur 15 MSA, (c) Biji tua (36 MSA)

\section{Daya Tumbuh}

Penghitungan daya tumbuh dimulai ketika tunas muncul ke permukaan tanah yang dibungkus oleh seludang. Tunas muncul pada 1646 HST, yakni antara minggu ke-1 hingga minggu ke-6 (Turhadi dan Indriyani, 2015). Hasil uji F menunjukkan bahwa persentase daya tumbuh lapang benih iles-iles dari ketiga teknik budi daya tidak berbeda nyata. Pertumbuhan kecambah disajikan dalam bentuk diagram garis (Gambar 2).

Berdasarkan Gambar 2, terdapat indikasi bahwa benih yang dipanen dari tanaman hasil induksi $\mathrm{GA}_{3}$ mengalami pertumbuhan lebih lambat daripada benih yang dipanen dari tanaman yang dibudidayakan jenuh air dan tanah. Namun, setelah umur 26 HST, pertumbuhannya tidak berbeda lagi. Benih hasil tanaman jenuh air lebih cepat berkecambah dibandingkan dengan benih hasil induksi $\mathrm{GA}_{3}$ dan budi daya tanah.

Pada akhir pengamatan, terlihat bahwa daya tumbuh iles-iles mencapai 91,25-95,83\% pada umur 46 HST. Dibandingkan dengan $A$. variabilis, daya tumbuh $A$. muelleri dari tiga teknik budi daya yang berbeda termasuk normal. Sugiyama and Santosa (2008) menyatakan bahwa daya tumbuh A. variabilis mencapai $65-96 \%$ dari bahan tanam benih. Hal tersebut mengindikasikan adanya kemungkinan untuk produksi benih dengan budi daya iles-iles jenuh air dan induksi $\mathrm{GA}_{3}$. 


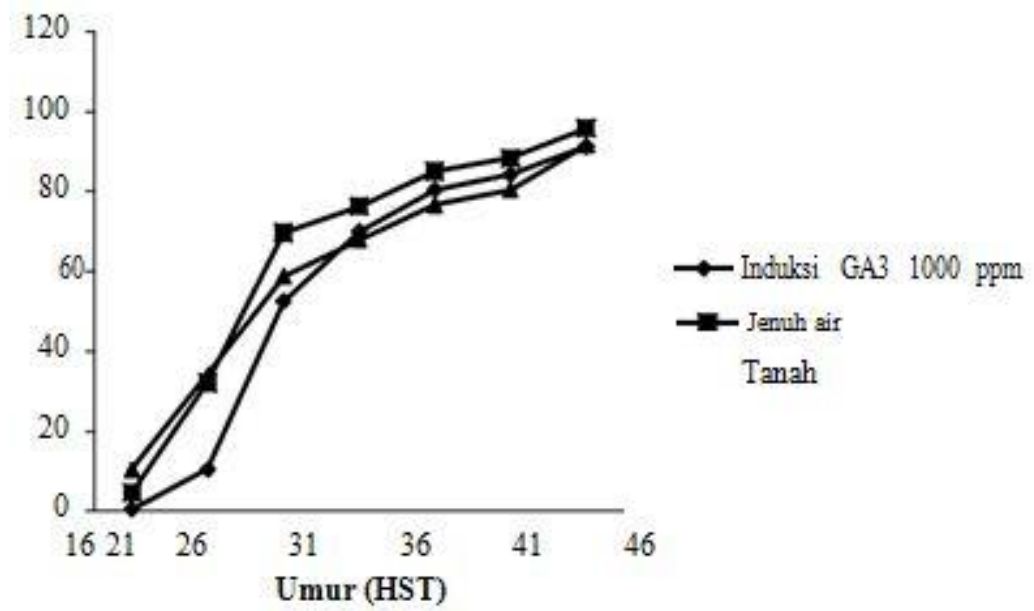

Gambar 2. Perbandingan rata-rata daya tumbuh benih iles-iles dari tiga teknik budi daya yang berbeda

\section{Morfologi Daun pada Bibit Iles-iles}

Secara umum, terdapat perbedaan morfologi daun pertama, kedua, dan ketiga pada iles-iles (Gambar 3a,b, dan c). Daun pertama memiliki 5 anak daun dengan tepi daun yang berwarna pink. Hal tersebut sesuai dengan pernyataan Sugiyama dan Santosa (2008) bahwa warna tepi daun pada Amorphophallus muelleri adalah pink dengan warna hijau pada bagian lainnya.

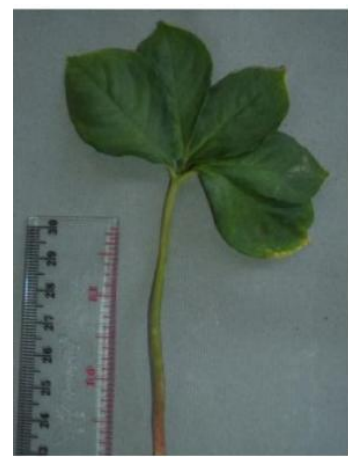

a)

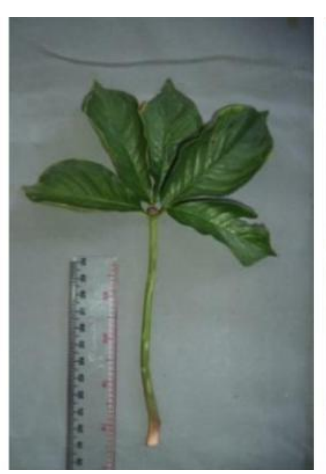

b)

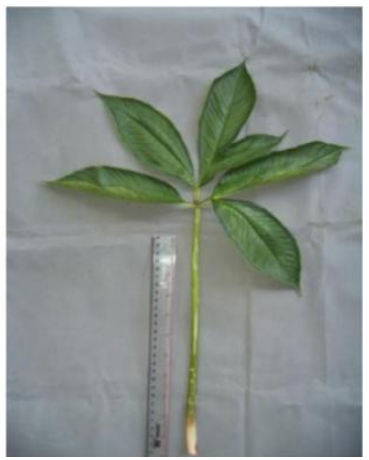

c)

Gambar 3. Morfologi daun iles-iles. (a) Daun pertama, (b) Daun kedua, (c) Daun ketiga

Daun kedua memiliki jumlah anak daun yang sama dengan daun pertama. Daun ketiga memiliki 6 anak daun. Jumlah anak daun dari setiap asal benih cenderung sama sehingga perlakuan asal benih tidak berpengaruh terhadap jumlah anak daun. Adapun daun kedua dan ketiga memiliki ukuran yang lebih besar dari daun pertama. Menurut Sugiyama dan Santosa (2008) ketika daun mencapai ukuran maksimal, primordia dan selubung daun selanjutnya akan lebih besar ukurannya. Jumlah daun akan terus bertambah dan berkembang selama fase vegetatif. Pada tahun pertama, A. paeoniifolius dapat memproduksi 2-5 daun dengan 2-3 daun dapat hidup bersamaan. Hal tersebut sebanding dengan hasil penelitian bahwa A. muelleri memiliki 3-4 daun pada tahun pertamanya.

\section{Panjang petiol}

Pengukuran panjang petiol dan lebar tajuk tanaman daun pertama dilakukan mulai 77 HST karena merujuk pada Turhadi dan Indriyani (2015) yang menyatakan bahwa daun pertama akan membuka sempurna 1-4 minggu setelah munculnya bakal plumula. Panjang petiol daun pertama dari benih asal budi daya jenuh air dan asal tanah berbeda nyata pada umur 91-105 HST. Petiol daun pertama dari benih asal budi daya tanah lebih panjang daripada petiol asal budi daya jenuh air. Berdasarkan Tabel 1, panjang petiol daun pertama iles-iles maksimal adalah $6,00 \mathrm{~cm}$ yaitu pada 119 HST. Setelah 119 HST, daun pertama tidak mengalami pertumbuhan lagi beriringan dengan munculnya daun kedua.

Panjang petiol maksimal daun kedua yaitu $9,50 \mathrm{~cm}$ pada $133 \mathrm{HST}$. Setelah $133 \mathrm{HST}$, panjang petiol daun kedua tidak mengalami pertumbuhan beriringan dengan munculnya daun ketiga. Panjang petiol daun kedua dari ketiga asal benih tidak berbeda nyata. Hal tersebut mengindikasikan bahwa perbanyakan benih dengan induksi $\mathrm{GA}_{3}$ dan jenuh air menghasilkan 
tajuk yang sama dengan teknik budi daya tanah. Seludang daun ketiga mulai muncul pada 105 HST, namun mulai tumbuh pesat pada rentang waktu 119-147 HST. Hasil uji F menunjukkan bahwa petiol daun ketiga memiliki panjang maksimal pada 147 HST yaitu berkisar 19,0028,50

$\mathrm{cm}$.

Tabel 1. Perbandingan nilai tengah panjang petiol $(\mathrm{cm})$ pada benih iles-iles asal tiga teknik budi daya yang berbeda

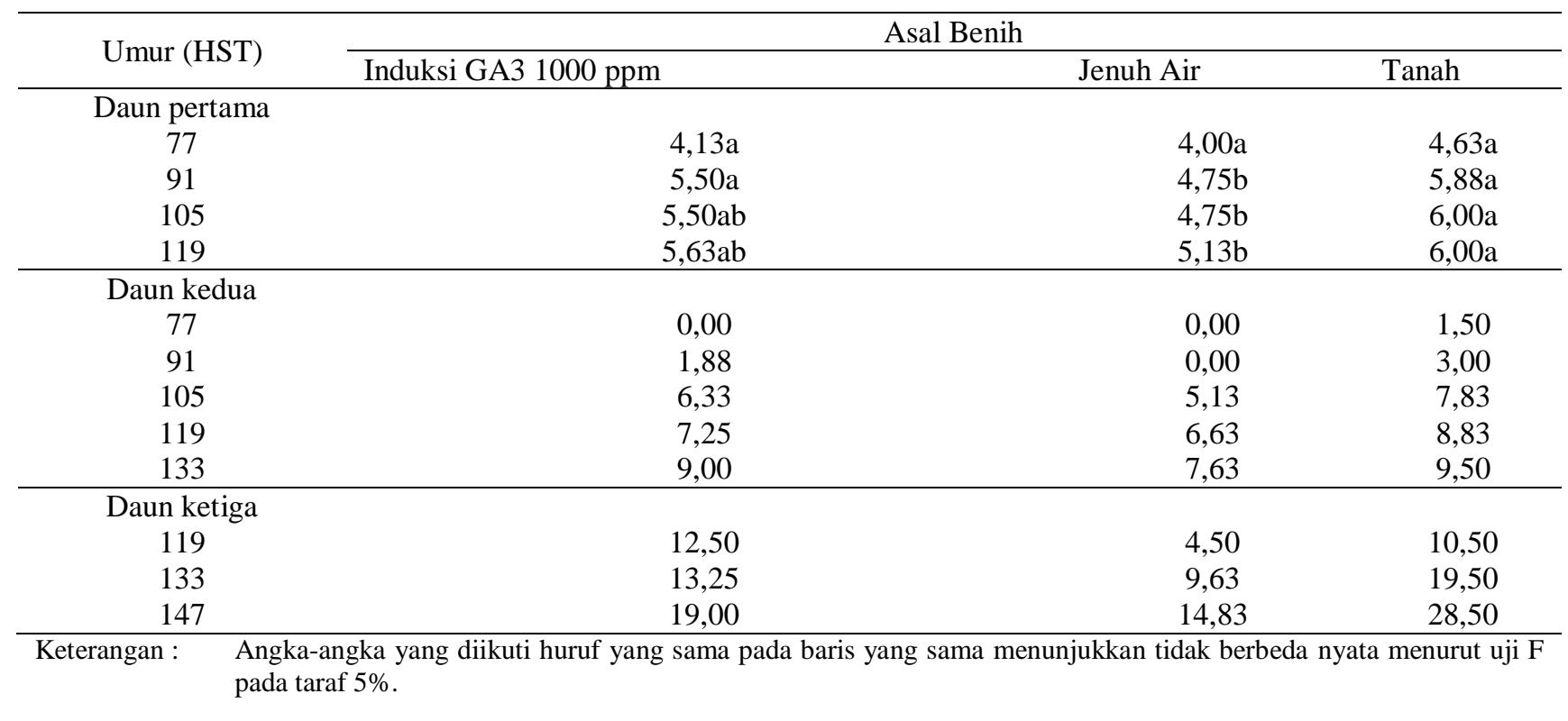

\section{Lebar kanopi}

Lebar kanopi mulai diamati ketika daun iles-iles mekar sempurna. Hasil analisis menunjukkan bahwa munculnya daun pertama serentak. Daun kedua mulai muncul 77 HST pada asal benih tanah, 91 HST pada asal benih induksi
$\mathrm{GA}_{3}$ dan $105 \mathrm{HST}$ asal benih jenuh air. Daun ketiga muncul 98 HST pada asal benih induksi $\mathrm{GA}_{3}$, dan 105 HST pada asal benih jenuh air dan tanah.

Tabel 2. Perbandingan nilai tengah lebar kanopi $(\mathrm{cm})$ pada benih iles-iles asal tiga teknik budi daya yang berbeda

\begin{tabular}{|c|c|c|c|}
\hline \multirow{2}{*}{ Umur (HST) } & \multicolumn{3}{|c|}{ Asal Benih } \\
\hline & Induksi GA3 1000 ppm & Jenuh Air & Tanah \\
\hline \multicolumn{4}{|l|}{ Daun pertama } \\
\hline 77 & 7,75 & 7,25 & 7,50 \\
\hline 91 & 7,90 & 7,43 & 8,80 \\
\hline 105 & 8,23 & 7,68 & 8,88 \\
\hline 119 & 8,17 & 7,75 & 8,88 \\
\hline \multicolumn{4}{|l|}{ Daun kedua } \\
\hline 77 & 0,00 & 0,00 & 2,25 \\
\hline 91 & 2,50 & 0,00 & 5,00 \\
\hline 105 & 9,83 & 8,00 & 12,17 \\
\hline 119 & 10,70 & 9,80 & 12,90 \\
\hline 133 & 12,00 & 10,33 & 14,17 \\
\hline \multicolumn{4}{|l|}{ Daun ketiga } \\
\hline 119 & 17,00 & 0,00 & 0,00 \\
\hline 133 & 23,50 & 14,83 & 27,50 \\
\hline 147 & 23,00 & 20,50 & 33,50 \\
\hline
\end{tabular}

Perlakuan asal benih tidak berpengaruh nyata terhadap lebar kanopi. Berdasarkan Tabel 2, dapat diketahui bahwa waktu pertumbuhan daun pertama, kedua, dan ketiga berbeda-beda. Daun pertama, kedua, dan ketiga asal benih induksi $\mathrm{GA}_{3}$ dapat hidup bersamaan pada 119 HST. Daun kedua dan ketiga asal benih jenuh air dan tanah dapat hidup bersamaan pada 133 HST. Hal tersebut sesuai dengan Sugiyama dan Santosa (2008) yang menyatakan bahwa lebih dari dua daun iles-iles dapat hidup bersamaan pada waktu yang sama. Sementara itu, daun kedua berkembang setelah daun pertama mengalami pertumbuhan maksimal. Begitu pula daun ketiga 
berkembang setelah pertumbuhan maksimal daun kedua.

\section{Komponen Hasil}

Panen dilakukan pada 34 MST, yaitu ketika semua tanaman telah memasuki fase dorman. Dorman ditandai dengan daun yang mulai layu (Jansen et al., 1996). Daun mulai dorman sejak 28 MST namun baru dorman secara menyeluruh pada 34 MST. Menurut Chairiyah et al (2014) waktu panen yang tepat adalah saat tanaman rebah karena kandungan glukomannan yang lebih tinggi daripada pemanenan sebelum atau sesudah tanaman rebah. Berdasarkan Tabel 3, kualitas umbi (diameter dan tinggi umbi) tidak dipengaruhi oleh asal benih dengan teknik budi daya yang berbeda. Artinya, untuk produksi benih bisa dilakukan dengan ketiga teknik budi daya.

Tabel 3. Perbandingan nilai tengah diameter dan tinggi $(\mathrm{cm})$ umbi pada benih iles-iles asal tiga teknik budi daya yang berbeda

\begin{tabular}{lccc}
\hline \multirow{2}{*}{ Peubah } & \multicolumn{3}{c}{ Asal Benih } \\
\cline { 2 - 4 } & Induksi GA3 $1000 \mathrm{ppm}$ & Jenuh air & Tanah \\
\hline Diameter1 & 4,22 & 5,83 & 5,18 \\
Diameter2 & 3,72 & 5,45 & 5,43 \\
Tinggi umbi & 2,92 & 4,30 & 4,21 \\
\hline
\end{tabular}

Ukuran umbi iles-iles meningkat dari tahun ke tahun sampai terbentuknya bunga (Sugiyama dan Santosa, 2008). Berdasarkan Tabel 4, bobot basah umbi mencapai 44,50-103,00 g. Bobot tersebut belum sesuai dengan yang diinginkan karena berdasarkan Santosa et al (2006) bobot umbi umur satu tahun A. muelleri dalam naungan $50 \%$ mencapai $243,1 \mathrm{~g}$ dan 217,5 g pada A. paeoniifolius. Sementara itu, untuk naungan $75 \%$ mencapai 403,8 g pada $A$. muelleri dan 282,3 g pada A. paeoniifolius.

Bobot basah umbi iles-iles dari ketiga teknik budi daya tidak berbeda nyata. Hal tersebut menunjukkan bahwa produksi umbi tidak dipengaruhi asal budi daya benih.

Tabel 4. Perbandingan nilai tengah bobot basah umbi pada benih iles-iles asal tiga teknik budi daya yang berbeda

\begin{tabular}{|c|c|c|}
\hline \multirow{2}{*}{ Perlakuan } & \multicolumn{2}{|c|}{ Bobot Basah Umbi (g) } \\
\hline & Tanaman contoh & Per bedeng \\
\hline Induksi $\mathrm{GA}_{3} 1000 \mathrm{ppm}$ & 44,50 & 1323,50 \\
\hline Jenuh air & 30,00 & 712,50 \\
\hline Tanah & 103,00 & 1027,50 \\
\hline
\end{tabular}

\section{KESIMPULAN}

Pertumbuhan iles-iles dari benih asal teknik budi daya induksi $\mathrm{GA}_{3}$, jenuh air, dan tanah tidak berbeda nyata. Demikian pula dengan produksi iles-iles yang meliputi diameter umbi, tinggi umbi, dan bobot basah umbi tidak berbeda nyata pada ketiga teknik budi daya. Benih hasil teknik budi daya tanah, induksi $\mathrm{GA}_{3}$, dan jenuh air pada iles-iles tidak mempengaruhi pertumbuhan dan produksi.

\section{DAFTAR PUSTAKA}

Chairiyah, N., N. Harijati, R. Mastuti. 2014. Pengaruh waktu panen terhadap kandungan glukomannan pada umbi porang (Amorphophallus muelleri Blume) periode tumbuh ketiga. Research journal of life science 1(1):37-42.

Jansen, P.C.M., C. Van Der Wilk, W.L.A. Hetterscheid. 1996. Plant Resources of
South-East Asia 9 : Plants Yielding Nonseed Carbohydrate. Prosea Foundation : Bogor.

Prana, M.S. 2007. Studi biologi pembungaan pada talas (Colocasia esculenta (L.) Schott.). Biodiversitas 8(1):63-66 Santosa E., Sugiyama N., Nakata M., and Lee O. N., Trikoesoemaningtyas, and Soepandie D. 2006. Flower induction in elephant foot yams using gibberellic acid $\left(G A_{3}\right)$. Jpn. J. Trop. Agr. 50(2):82-86.

Santosa, E., N. Sugiyama, M. Nakata, O.N. Lee. 2006. Growth and corm production at Amorphophallus at different shading levels in Indonesia. Jpn. J. Trop. Agr. 50(2):87-91.

Santosa, E. 2014. Pengembangan tanaman ilesiles tumpangsari untuk kesejahteraan petani dan kemandirian industri pangan 
nasional. Risalah Kebijakan Pertanian dan Lingkungan. 1(2):73-79.

Santosa, E., A.P. Lontoh, A. Kurniawati, M. Sari, N. Sugiyama. 2016. Flower development and its implication for seed production on Amorphophallus muelleri Blume (Araceae). J. Hort. Indonesia 7(2):63-72.
Sugiyama, N., E. Santosa. 2008. Edible Amorphophallus in Indonesia-Potential Crops in Agroforestry. Gajah Mada University Press, Yogyakarta.

Turhadi, S. Indriyani. 2015. Uji daya tumbuh porang (Amorphophallus muelleri Blume) dari berbagai variasi potongan biji. Jurnal Biotropika 3(1):1-6. 